\title{
A review of HIV-specific patient-reported measures of perceived barriers to antiretroviral therapy adherence: what themes are they covering?
}

\author{
Kim Engler ${ }^{1^{*}}$, Isabelle Toupin ${ }^{1}$, Serge Vicente ${ }^{3}$, Sara Ahmed ${ }^{2}$ and Bertrand Lebouché ${ }^{1}$
}

\section{Background}

In 2017, there were 2.2 million people living with human immunodeficiency virus (PLHIV) in western and central Europe and North America, with approximately 77\% accessing antiretroviral therapy (ART) [1]. However, only $63 \%$ of PLHIV on ART are estimated to attain the ideal of at least $95 \%$ adherence [2]. Indefinitely maintaining ART adherence may be extremely difficult, given the numerous factors that can impede it [3]. While newer, more potent ART regimens may make perfect adherence less necessary [4], adherence difficulties are tied to a range of medically relevant psychosocial and structural issues. These include depression, alcohol/substance misuse, and health service-related barriers [5]. Indeed, regularly identifying a patient's potential barriers to ART adherence is explicitly recommended in some HIV treatment guidelines [6]. Doing so could help address previously undetected problems and prevent virologic failures. Nevertheless, how best to do this remains less clear. Given the many recognized barriers to ART adherence, such an assessment could prove time-consuming [7].

Patient-reported outcome measures (PROM) could offer a solution and their use is growing in healthcare [8]. While published initiatives of their implementation in HIV care are few (e.g., $[9,10])$, using them to screen for barriers prior to the clinic visit could offer a quick and affordable solution and lead to more patient-centered counseling and intervention [7]. Yet there may be few comprehensive HIV-specific self-report measures for capturing and succinctly scoring patient perceived barriers to properly taking ART in developed countries [11]. It is also unclear to

\footnotetext{
* Correspondence: kimcengler@gmail.com

'Centre for Outcomes Research \& Evaluation, Research Institute of the McGill University Health Centre, 5252 de Maisonneuve Blvd, Montreal, QC H4A 3S5, Canada

Full list of author information is available at the end of the article
}

what extent PLHIV participated in their creation, considering that patient involvement is deemed essential to a PROM's content validity [12]. In a previous research phase, our team generated a conceptual framework of ART adherence barriers based on a synthesis of qualitative studies with PLHIV in developed countries, to design a new PROM for use in routine HIV care in Canada and France [13]. With this review, we seek to: 1) identify existing patient-reported measures of barriers to ART adherence used in developed countries, and 2) examine their coverage of this patient-informed conceptual framework.

\section{Methods \\ Conceptual framework \\ Forty-one qualitative studies with adult PLHIV on bar- riers to ART adherence in developed countries were syn- thesized with thematic analysis to create our framework. It defines 6 broad interrelated themes under which are grouped 20 subthemes of barriers. Details on this frame- work are published elsewhere [13].}

\section{Search strategy and inclusion criteria}

On July 4, 2018, four databases were searched for patient-reported measures of barriers to ART adherence: EMBASE, MEDLINE, PsychINFO, and Health and Psychological Instruments. Searches were adapted to each database and targeted words in the abstract referring to: 1) HIV; 2) adherence; 3) barriers; and 4) antiretroviral therapy. The searches were limited to English-language publications from 1996 and human adults (18 or 19 years and older). The precise search strings used are available upon request. Duplicates of all identified records were eliminated. Then, the title and abstract of each record were screened and the full-texts of all potentially relevant records were examined. Records of conference abstracts and opinion articles were excluded. 
A tenth of deduplicated records and 15\% of full-texts were reviewed by IT to calculate interrater reliability with Cohen's kappa [14] and percent agreement. The references of retained full-texts were also searched.

Instruments (e.g., questionnaires, checklists, subscales) were included if they served to quantify perceived barriers to ART adherence. Specifically, eligible instruments allowed respondents to indicate factors that prevented them from taking the medication, as prescribed. Instruments also needed to be HIV-specific (i.e. designed or adapted for PLHIV), used in developed countries [15], based on patient report, and published in English no earlier than 1996, when combination ART became the new standard of care. If several versions of an instrument were found, only the most complete version was retained, unless item content differed meaningfully between them, in which case all were retained. Instruments with fewer than 3 items were excluded. They were also excluded if all relevant instrument items were not obtained, after contacting the author(s).

\section{Data extraction}

We extracted the following information for each retained measure: instrument and/or study name, if appropriate; instrument items; publication or version year of the document from which the instrument items were extracted; number of items; author description of what the instrument measures; mention and form of patient involvement in its development; and first author and year of the research article publication affiliated with the measure. Based on Weiring et al. [16], patient involvement was defined as explicit mention of patient participation in either determining the outcome measured (e.g., in developing its framework or domains); generating items; and/or verifying content validity, including comprehensibility (e.g., through interviews).

\section{Analysis of thematic coverage}

Our methods draw on the approach taken by O'Brien et al. [17]. To compare instrument items against our conceptual framework, we used content analysis [18], allowing for the creation of new themes to accommodate the items. We sought to map each item to the framework, using the qualitative analysis software, Atlas.ti (v8). Items could be coded for several subthemes. KE mapped all instrument items. IT mapped $10 \%$ of the items $(n=43)$ to calculate percent agreement on each item's main subtheme. To assess coverage of the concept of barriers to ART adherence, instrument breadth (representation of all original framework themes) and depth (representation of all original subthemes) were evaluated. Coverage was expressed with means (i.e. average instrument breadth and depth) and proportions (e.g., percentage of (sub)themes represented). We did not consider the number of items representing each (sub)theme.

\section{Results \\ Search results}

We reviewed a total of 1540 records, removing $730 \mathrm{du}$ plicates (see Fig. 1). Following deduplication and exclusion of irrelevant records, based on title/abstract screening, the full-texts of 59 records were examined. Percent agreement was $90.1 \%$ for the deduplicated records and Cohen's Kappa was 0.62, indicating substantial agreement [14]. Percent agreement for the full text articles was $88.9 \%$ and Cohen's kappa was also 0.62 . Relevant records and their references yielded 31 instruments for inclusion in the review. Two instruments were excluded $[19,20]$, given incomplete access to their items.

\section{Instrument description}

Table 1 provides details on the instruments. Descriptions of an instrument could vary. All but one were described as measures of "reasons" (for "missing a dose", "taking treatment breaks", "nonadherence", etc.) $(n=21)$ or "barriers" (to "adherence", "taking antiretrovirals", etc.) $(n=$ $4)$ or both $(n=5)$. They originated from the Unites States $(n=20)$; Western Europe: Denmark, Germany, United Kingdom, and Sweden $(n=4)$; Australia $(n=3)$; Canada $(n=3)$; and Romania $(n=1)$. On average, they contained 13.5 items $(S D=5.8)$, with a range of 3 to 23 . For 9 measures, patient involvement was reported. Its specified forms included interviews $(n=5)$, consultation $(n=3)$, and piloting/pretesting/pre-experimentation $(n=$ $3)$. The version or publication year of the included instruments ranged from 1999 to 2017. An indication of their influence, authors reported adapting the Adult AIDS Clinical Trials Group (AACTG) adherence instruments [21] for 8 measures. Two original AACTG instruments were also included.

\section{Thematic coverage: instrument breadth and depth}

Percent agreement for the item mapping was $88.4 \%$. Thirty-five items were not mapped to the framework. Twenty-three of these, from 5 instruments, concerned "Likely clinically justified reasons" for not taking a specific antiretroviral agent or treatment (e.g., "Recommended by doctor", "Changing regimens"). These items did not qualify as barriers, as they concerned situations in which the medication no longer seemed clinically indicated. Similarly, 4 other items related to "How a person was non-adherent" (e.g., "Doubled up on a dose because you missed a dose"), falling beyond the framework's scope. Finally, 8 items $(/ 408,2 \%)$ could not be confidently mapped, for lack of clarity (e.g., "You had a bad event happen that you felt was related to taking the pills"). 


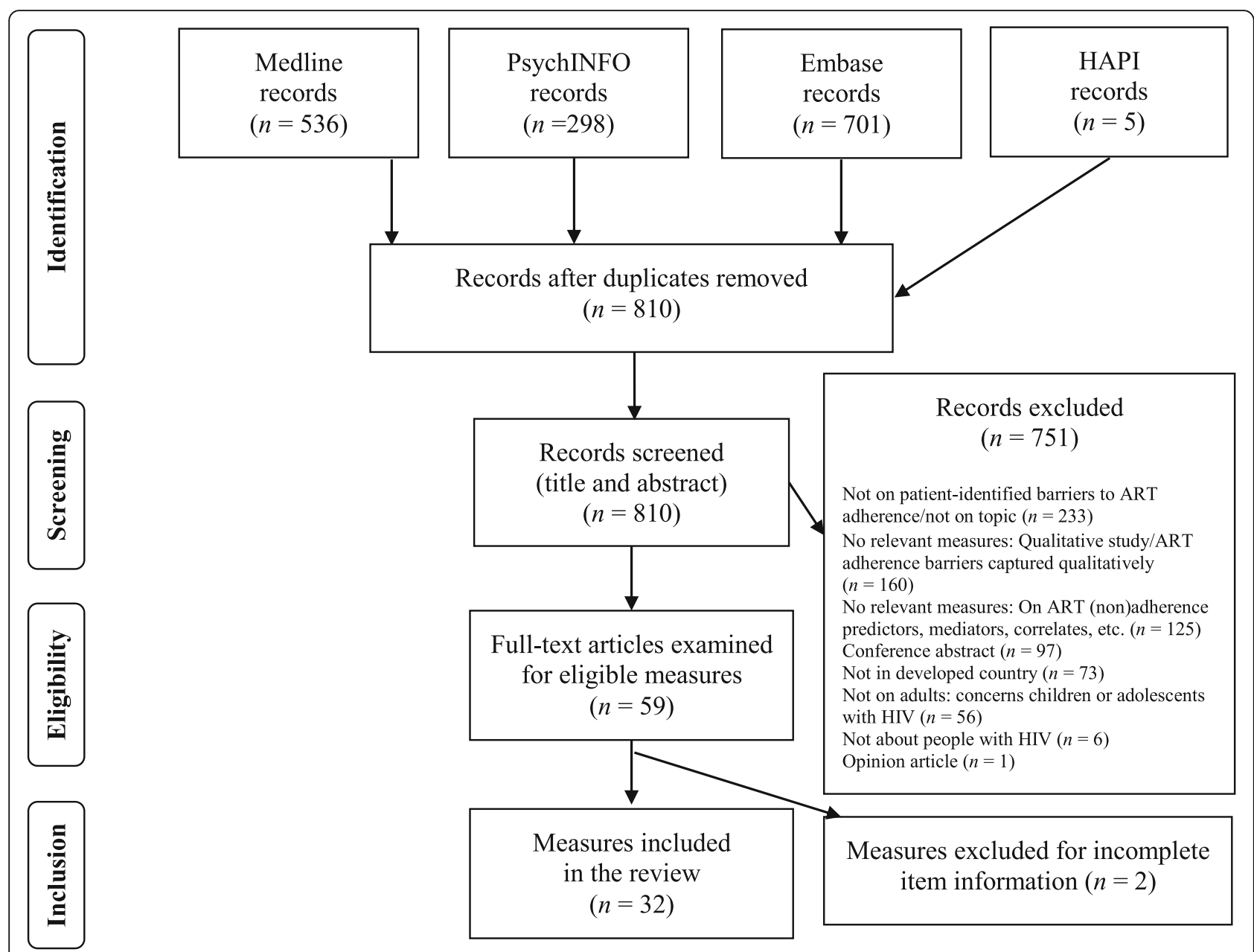

HAPI: Health and Psychological Instruments; ART: antiretroviral therapy.

Fig. 1 Search flow diagram

Table 2 reports the findings on instrument breadth and depth. On average, breadth was $4.4 / 6$ themes $(S D=$ 1.2). The majority of instruments covered the broad themes of "Lifestyle factors" (94\%), the "Characteristics of antiretroviral therapy" (90\%), "Cognitive and emotional aspects" (84\%), the "Social and material context" $(84 \%)$ and the "Health experience and state" (61\%). Less than a quarter $(23 \%)$ covered the "Healthcare services and system" theme. As to depth, it was, on average, 7.0/ 20 subthemes $(S D=3.0)$. Individual subthemes were addressed in between $3 \%$ and $88 \%$ of instruments. A majority of instruments contained at least one item on the subthemes of "Demands and organization of daily life" $(88 \%)$ (e.g., change/break in daily routine, away from home, forgot, fell asleep/overslept, ran out of pills); "Side effects" (81\%); "Affect" (71\%), especially, feeling depressed/overwhelmed; "Beliefs" about adherence, ART or HIV (63\%) (e.g., felt like drug was toxic/harmful);
"Instructions" for ART (61\%) (e.g., too many pills, problems taking pills at specific times); "HIV stigma and privacy" (61\%) (e.g., did not want others to notice); and "Bodily signals" (52\%), particularly, feeling sick or ill.

\section{Discussion}

This review builds on our previous work. It mapped the items of existing HIV-specific measures used in developed countries of patient-reported barriers to ART adherence to our patient-informed conceptual framework. On average, the 31 instruments identified had a conceptual breadth of $73 \%$ and a depth of only $35 \%$. Additionally, patient involvement was reported for the development of less than a third of instruments (29\%). Together, these findings raise concerns about the content validity of many measures, if they are intended to capture patient perceived ART adherence barriers. 
Table 1 Instrument characteristics $(n=31)$

\begin{tabular}{|c|c|c|c|c|c|c|c|c|}
\hline \multirow[t]{2}{*}{ \# } & \multirow[t]{2}{*}{ Instrument/study name (if appropriate) } & \multirow{2}{*}{$\begin{array}{l}\text { First author of } \\
\text { related } \\
\text { publication }\end{array}$} & \multirow[t]{2}{*}{$\begin{array}{l}\text { Version } \\
\text { year }\end{array}$} & \multirow[t]{2}{*}{ Country $^{\mathrm{b}}$} & \multirow[t]{2}{*}{ Description } & \multicolumn{2}{|c|}{$\begin{array}{l}\text { Patient } \\
\text { involvement }\end{array}$} & \multirow[t]{2}{*}{$\begin{array}{l}\text { No. } \\
\text { items }^{\mathrm{a}}\end{array}$} \\
\hline & & & & & & Yes & No & \\
\hline 1 & $\begin{array}{l}\text { Adult AIDS Clinical Trials Group (AACTG), } \\
\text { Adherence Baseline Questionnaire II, 2001, } \\
\text { Section C }\end{array}$ & $\begin{array}{l}\text { Chesney et al. } \\
2000 \text { [21] }\end{array}$ & 2001 & USA & $\begin{array}{l}\text { "Reasons why people may miss taking } \\
\text { their medications"c }\end{array}$ & & $\bullet$ & 14 \\
\hline 2 & $\begin{array}{l}\text { AACTG, Adherence Barriers Questionnaire, } \\
\text { 2008, Question } 2\end{array}$ & $\begin{array}{l}\text { Chesney et al. } \\
2000 \text { [21] }\end{array}$ & 2008 & USA & $\begin{array}{l}\text { "Reasons why people may miss taking } \\
\text { their medications"c }\end{array}$ & & $\bullet$ & 22 \\
\hline 3 & - & $\begin{array}{l}\text { Amico et al. } \\
2007[22]\end{array}$ & 2007 & USA & $\begin{array}{l}\text { "Reasons for last having missed a } \\
\text { dose of ART medication" }\end{array}$ & & $\bullet$ & 14 \\
\hline 4 & AACTG adherence instrument -Modified & $\begin{array}{l}\text { Barfod et al. } \\
2006[23]\end{array}$ & 2006 & Denmark & $\begin{array}{l}\text { "Reasons for } \\
\text { missing a dose" }\end{array}$ & $\bullet$ & & 22 \\
\hline 5 & - & $\begin{array}{l}\text { Boretzki et al. } \\
2017 \text { [24] }\end{array}$ & 2017 & Germany & $\begin{array}{l}\text { "Reasons for nonadherence to } \\
\text { antiretroviral therapy" }\end{array}$ & & $\bullet$ & 9 \\
\hline 6 & $\begin{array}{l}\text { CEAT-VIH (Cuestionario para la Evaluacio'n de } \\
\text { la Adhesio'n al Tratamiento Antirretroviral en } \\
\text { Personas con Infeccio'n por VIH y Sida) } \\
\text {-Romanian adaptation }\end{array}$ & $\begin{array}{l}\text { Dima et al. } \\
2013 \text { [25] } \\
\text { (based on } \\
\text { Remor 2002) }\end{array}$ & 2013 & Romania & $\begin{array}{l}\text { "Barriers to adherence" -"Antecedents } \\
\text { of non-adherence behaviours" }\end{array}$ & $\bullet$ & & 3 \\
\hline 7 & - & $\begin{array}{l}\text { Durante et al. } \\
2003 \text { [26] }\end{array}$ & 2003 & USA & $\begin{array}{l}\text { "Reasons for missing doses of } \\
\text { medication" }\end{array}$ & $\bullet$ & & 14 \\
\hline 8 & - & $\begin{array}{l}\text { Gifford et al. } \\
2000[27]\end{array}$ & 2000 & USA & $\begin{array}{l}\text { "Reasons for missing antiretroviral } \\
\text { doses" }\end{array}$ & & $\bullet$ & 16 \\
\hline 9 & $\begin{array}{l}\text { Questionnaire on Taking Antiretroviral } \\
\text { Medication, Questions } 3 \text { and } 4\end{array}$ & $\begin{array}{l}\text { Godin et al. } \\
2003 \text { [28] }\end{array}$ & 2003 & Canada & $\begin{array}{l}\text { "Situations that might have hampered } \\
{[\ldots . .] \text { regular adherence to medication" }}\end{array}$ & $\bullet$ & & 8 \\
\hline 10 & HIV Futures 3 Survey & $\begin{array}{l}\text { Grierson et al. } \\
2004 \text { [29] }\end{array}$ & 2004 & Australia & $\begin{array}{l}\text { "Reasons for taking treatment breaks"- } \\
\text { Lifestyle and clinical reasons }\end{array}$ & $\bullet$ & & 16 \\
\hline 11 & HIV Futures 7 Survey & $\begin{array}{l}\text { Grierson et al. } \\
2013 \text { [30] }\end{array}$ & 2013 & Australia & "Reasons for stopping ARV" & $\bullet$ & & 7 \\
\hline 12 & HIV Futures 7 Survey & $\begin{array}{l}\text { Grierson et al. } \\
2013[30]\end{array}$ & 2013 & Australia & $\begin{array}{l}\text { "Reasons for taking breaks" -Lifestyle } \\
\text { and clinical reasons }\end{array}$ & $\bullet$ & & 14 \\
\hline 13 & - & $\begin{array}{l}\text { Harzke et al. } \\
2004[31]\end{array}$ & 2004 & USA & $\begin{array}{l}\text { "Perceived barriers to taking } \\
\text { antiretrovirals" -"Forgetting to take } \\
\text { medications" scale }\end{array}$ & & $\bullet$ & 3 \\
\hline 14 & $\begin{array}{l}\text { HCSUS 2nd Follow-up, Section } 4.5 \text { Antiretro- } \\
\text { viral and Opportunistic Infection Medication }\end{array}$ & n.a. & 1997 & USA & $\begin{array}{l}\text { "Reasons [...] why you stopped taking } \\
\text { this antiretroviral medication(s)" }\end{array}$ & & $\bullet$ & 11 \\
\hline 15 & - & $\begin{array}{l}\text { Kalichman } \\
\text { et al. } 1999 \text { [32] }\end{array}$ & 1999 & USA & $\begin{array}{l}\text { "Perceived barriers to treatment and } \\
\text { reasons for non-adherence" }\end{array}$ & & $\bullet$ & 9 \\
\hline 16 & - & $\begin{array}{l}\text { Kalichman } \\
\text { et al. } 2017 \text { [33] }\end{array}$ & 2017 & USA & "Barriers to adherence" & & $\bullet$ & 15 \\
\hline 17 & $\begin{array}{l}\text { AACTG adherence instrument -Supplemented } \\
\text { for the Vancouver Injection Drug Users Study } \\
\text { (VIDUS) }\end{array}$ & $\begin{array}{l}\text { Kerr et al. } \\
2004[34]\end{array}$ & 2004 & Canada & $\begin{array}{l}\text { "Reasons for missing doses of } \\
\text { HAART" }\end{array}$ & & $\bullet$ & 13 \\
\hline 18 & $\begin{array}{l}\text { Vancouver Injection Drug Users Study (VIDUS) } \\
\text { questionnaire }\end{array}$ & $\begin{array}{l}\text { Kerr et al. } \\
2005[35]\end{array}$ & 2005 & Canada & "Reasons for discontinuing HAART" & & $\bullet$ & 15 \\
\hline 19 & $\begin{array}{l}\text { AACTG adherence instrument -Adapted for } \\
\text { the Multicenter AIDS Cohort Study (MACS), } \\
\text { Medication Adherence Form }\end{array}$ & $\begin{array}{l}\text { Kleeberger } \\
\text { et al. } 2001 \text { [36] }\end{array}$ & 2001 & USA & $\begin{array}{l}\text { "Reasons for missing }[. . .] \\
\text { medications" }\end{array}$ & $\bullet$ & & 15 \\
\hline 20 & $\begin{array}{l}\text { The study to understand the natural history of } \\
\text { HIV/AIDS in the era of effective therapy (SUN) } \\
\text { study, questionnaire }\end{array}$ & $\begin{array}{l}\text { Kyser et al. } \\
2011[37]\end{array}$ & 2011 & USA & $\begin{array}{l}\text { "Main reason }[\ldots .] \text { for missing } \\
\text { medication" }\end{array}$ & & $\bullet$ & 6 \\
\hline 21 & - & $\begin{array}{l}\text { Macdonell } \\
\text { et al. } 2013 \text { [38] }\end{array}$ & 2013 & USA & "Barriers to medication adherence" & & $\bullet$ & 18 \\
\hline 22 & $\begin{array}{l}\text { Community Programs for Clinical Research on } \\
\text { AIDS (CPCRA), Antiretroviral Medication Self- } \\
\text { Report -Form 646, Version 4, 2003, Section C, } \\
\text { Question } 2\end{array}$ & $\begin{array}{l}\text { Mannheimer } \\
\text { et al. } 2002 \text { [39] }\end{array}$ & 2003 & USA & $\begin{array}{l}\text { "Reasons why people miss taking their } \\
\text { antiretroviral drugs" }\end{array}$ & & $\bullet$ & 10 \\
\hline 23 & AACTG adherence instrument -Adapted & Murphy et al. & 2000 & USA & "Barriers to adherence"c & & $\bullet$ & 23 \\
\hline
\end{tabular}


Table 1 Instrument characteristics $(n=31)$ (Continued)

\begin{tabular}{|c|c|c|c|c|c|c|c|c|}
\hline \multirow[t]{3}{*}{ \# } & \multirow[t]{2}{*}{ Instrument/study name (if appropriate) } & \multirow{2}{*}{$\begin{array}{l}\text { First author of } \\
\text { related } \\
\text { publication }\end{array}$} & \multirow[t]{2}{*}{$\begin{array}{l}\text { Version } \\
\text { year }\end{array}$} & \multirow[t]{2}{*}{ Country $^{b}$} & \multirow[t]{2}{*}{ Description } & \multicolumn{2}{|c|}{$\begin{array}{l}\text { Patient } \\
\text { involvement }\end{array}$} & \multirow[t]{2}{*}{$\begin{array}{l}\text { No. } \\
\text { items }\end{array}$} \\
\hline & & & & & & Yes & No & \\
\hline & & $2000[40]$ & & & & & & \\
\hline 24 & $\begin{array}{l}\text { AACTG adherence instrument -Supplemented } \\
\text { by adolescent-specific issues for the Reaching } \\
\text { for Excellence in Adolescent Care and Health } \\
\text { (REACH) Project }\end{array}$ & $\begin{array}{l}\text { Murphy et al. } \\
2003[41]\end{array}$ & 2003 & USA & "Barriers to adherence" & & $\bullet$ & 19 \\
\hline 25 & $\begin{array}{l}\text { The HIV Epidemiology Research Study (HERS) } \\
\text { and Women's Inter-Agency HIV Study (WIHS), } \\
\text { substudy interview instruments }\end{array}$ & $\begin{array}{l}\text { Schuman } \\
\text { et al. } 2001 \text { [42] }\end{array}$ & 2001 & USA & $\begin{array}{l}\text { "Reasons that occasionally or } \\
\text { frequently interfered with adherence" }\end{array}$ & & $\bullet$ & 11 \\
\hline 26 & $\begin{array}{l}\text { US Military HIV Natural History Cohort Study } \\
\text { (NHS), HIV Medication Adherence History, } \\
\text { Form } 168.40 .1\end{array}$ & n.a. & 2010 & USA & "Reasons for missed doses" & & $\bullet$ & 23 \\
\hline 27 & $\begin{array}{l}\text { HIV Medication Self-Reported Nonadherence } \\
\text { Reasons (SNAR) Index }\end{array}$ & $\begin{array}{l}\text { Schönnesson } \\
\text { et al. } 2004 \text { [43] }\end{array}$ & 2004 & Sweden & $\begin{array}{l}\text { "Reasons for nonadherence to HIV- } \\
\text { medication" -Medication concerns } \\
\text { and routine disruptions }\end{array}$ & & $\bullet$ & 11 \\
\hline 28 & $\begin{array}{l}\text { AACTG adherence instrument -Modified for } \\
\text { the New York City Study }\end{array}$ & $\begin{array}{l}\text { Stirratt et al. } \\
2006[44]\end{array}$ & 2006 & USA & $\begin{array}{l}\text { "Reasons for missed } \\
\text { ART doses"c }\end{array}$ & & $\bullet$ & 22 \\
\hline 29 & - & $\begin{array}{l}\text { Walsh et al. } \\
2001[45]\end{array}$ & 2001 & UK & "Reasons for missing doses" & $\bullet$ & & 20 \\
\hline 30 & - & $\begin{array}{l}\text { Zorilla et al. } \\
2003[46]\end{array}$ & 2003 & $\begin{array}{l}\text { USA } \\
\text { (Puerto } \\
\text { Rico) }\end{array}$ & "Reasons for not taking medications" & & $\bullet$ & 8 \\
\hline 31 & - & $\begin{array}{l}\text { Zorilla et al. } \\
2003 \text { [46] }\end{array}$ & 2003 & $\begin{array}{l}\text { USA } \\
\text { (Puerto } \\
\text { Rico) }\end{array}$ & $\begin{array}{l}\text { "Reasons for taking medications at a } \\
\text { different time" }\end{array}$ & & $\bullet$ & 7 \\
\hline
\end{tabular}

\# = Number assigned to the instrument, as in Table 2

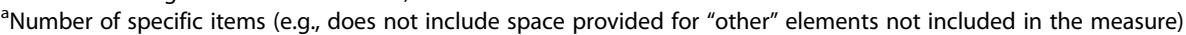

${ }^{\mathrm{b}}$ As indicated by the publications considered in this review (may not be exhaustive)

CAACTG adherence instrument or derivative thereof, as reported by developers

A PROM's content validity depends, in part, on patient perception of the measure's comprehensiveness (i.e. the inclusion of all key concepts) [12]. Our findings suggest a disparity between relevant and meaningful adherence barriers for patients (as identified in our previous literature search for our framework [13]), and what the identified instruments are measuring. On the level of broad themes, the least covered, "Healthcare services and system", was addressed by approximately 1 in 4 instruments. While this was also the least common theme in the qualitative studies contributing to the framework, two-thirds of them referred to it, especially to the "Patient-provider relationship" subtheme, described later. Among its other subthemes are "Health insurance" and "Pharmacy issues" (e.g., trouble going to the pharmacy; getting timely refills, for instance, due to stockouts). In resource rich settings, many PLHIV can have difficulty covering their pharmacy dispensing costs and travel costs to the clinic, with research suggesting that this financial stress is infrequently addressed in HIV care and associated with interrupting and ceasing ART [47]. Furthermore, "Health care team and system-related factors" is a major dimension of the World Health Organization model of factors that affect adherence in chronic conditions, including HIV [48]. Hence, it appears this theme requires representation in a comprehensive measure of ART adherence barriers.

On the level of subthemes, other significant disparities were apparent. While $54 \%$ of studies informing the framework mentioned the barrier of "Acceptance", that is, non-acceptance, denial or avoidance of one's HIV diagnosis, this was addressed in only $10 \%$ of measures. Furthermore, over three-quarters $(76 \%)$ of studies mentioned "Relations with others" as a barrier, most frequently, inadequate social support and relationship-related problems or stress. By comparison, only $29 \%$ of instruments contained any item on this subtheme. As a final example, while $59 \%$ of studies portrayed the "Patient-provider relationship" as a barrier, particularly in terms of mistrust of the provider, provider negativity/lack of supportiveness, 


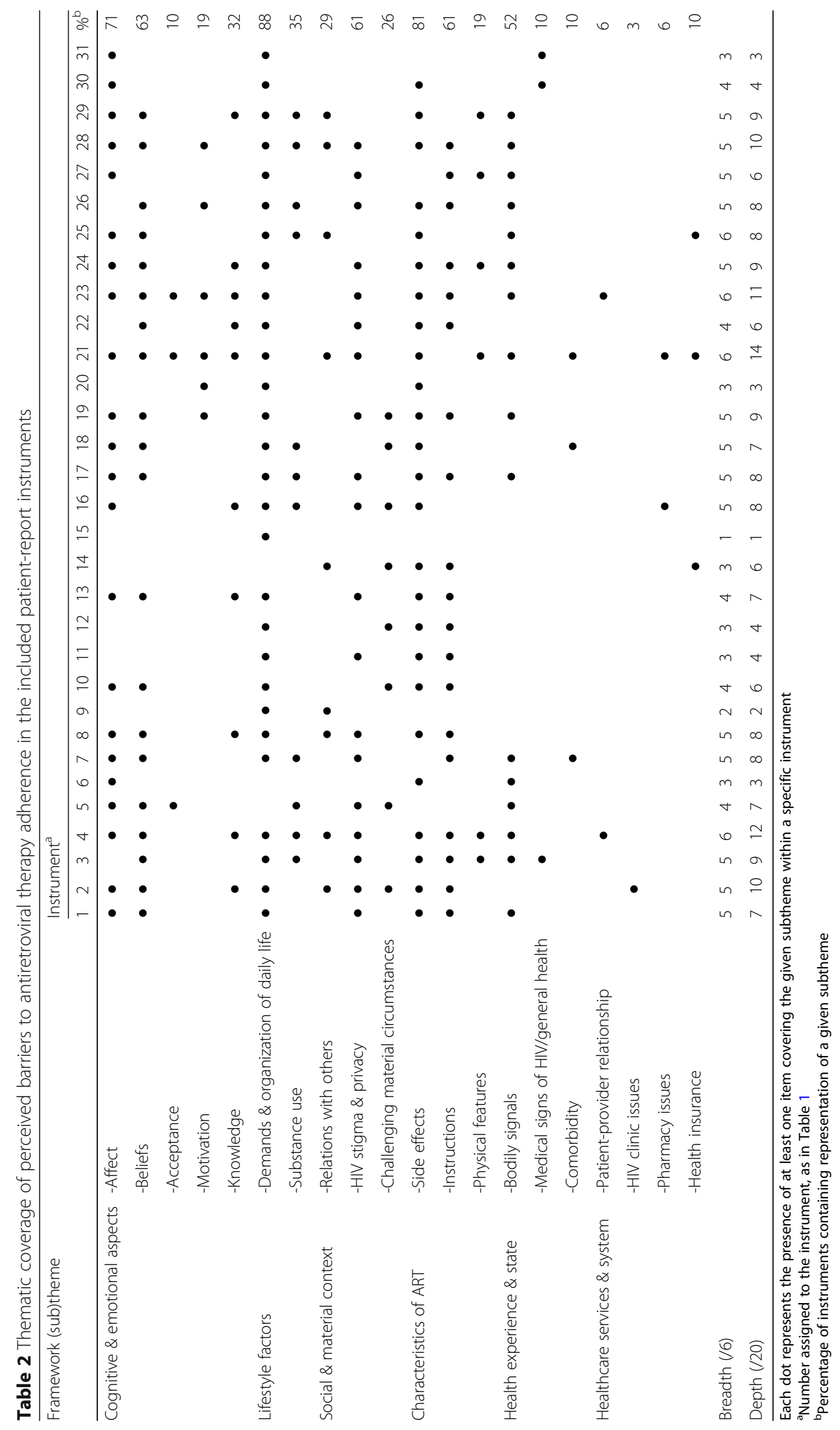


poor communication, and feelings of coercion/powerlessness, this subtheme was apparent in only 2 instruments/2 items.

Overall, our findings suggest that no measure of perceived barriers to ART adherence, as defined, may sufficiently capture this concept. A lack of comprehensiveness has implications for our understanding of the ART adherence barriers experienced by PLHIV, the estimation of their prevalence, and, ultimately, the design of patientcentered interventions to address them. The infrequent patient involvement observed in the measures' development may offer some explanation, if reported involvement reflects actual involvement.

This review is limited by the search strategy employed; we did not attempt to locate all existing instruments, instrument versions or validation studies per instrument. No data was extracted on the measures' psychometric properties which may shed further light on the findings. Nevertheless, the results presented support the development of our PROM, the content of which will be evaluated by PLHIV and providers in Canada and France with online Delphi techniques [49].

\section{Abbreviations}

AACTG: Adult AIDS Clinical Trial Group; AIDS: Acquired Immune Deficiency Syndrome; ART: Antiretroviral therapy; HIV: Human immunodeficiency virus; PLHIV: People living with HIV; PROM: Patient-reported outcome measure

\section{Acknowledgements}

Not applicable.

\section{Funding}

This study was conducted as a part of the I-Score Study which is supported in part by the Canadian Institutes of Health Research's HIV Clinical Trials Network [CTN 283], a research grant from the Investigator-Initiated Studies Program of Merck Canada, Inc. [IISP-53538], and the Quebec Strategy for Patient-Oriented Research Support Unit -Methodological Development Platform [M006]. It was also performed within the activities of a Strategy for Patient-Oriented Research (SPOR) Mentorship Chair in Innovative Clinical Trials (www.cihr-irsc.gc.ca) [383427]. Funding bodies had no role in the design, conduct or reporting of this study.

\section{Availability of data and materials}

The database records identified by the literature search and their classification, as indicated in Fig. 1, are available from the corresponding author on reasonable request, as is the Atlas.ti report of the item mapping (i.e. all codes generated and their content).

\section{Authors' contributions}

KE designed and conducted the review, with co-author input, and drafted the manuscript. Interrater reliability and agreement were verified with IT and calculated, in consultation, with SV. All authors contributed to the manuscript's content and approved its final version.

\section{Ethics approval and consent to participate}

Not applicable.

\section{Consent for publication}

Not applicable.

\section{Competing interests}

$\mathrm{KE}$ and $\mathrm{BL}$ are co-principal investigators of a study to develop a new PROM of patient-identified barriers to ART adherence with significant stakeholder engagement (the I-Score Study, clinicaltrials.gov identifier: NCT02586584).

\section{Publisher's Note}

Springer Nature remains neutral with regard to jurisdictional claims in published maps and institutional affiliations.

\section{Author details}

${ }^{1}$ Centre for Outcomes Research \& Evaluation, Research Institute of the McGill University Health Centre, 5252 de Maisonneuve Blvd, Montreal, QC H4A 355, Canada. ${ }^{2}$ School of Physical \& Occupational Therapy, Faculty of Medicine, McGill University, 3654 prom Sir-William-Osler, Montreal, QC H3G 1Y5, Canada. ${ }^{3}$ Department of Mathematics and Statistics, University of Montreal, 2920 chemin de la Tour, Montreal, QC H3T 1J4, Canada.

Received: 3 December 2018 Accepted: 8 May 2019 Published online: 27 June 2019

\section{References}

1. UNAIDS (2018). Factsheet- world AIDS day 2018. Available at: http://www. unaids.org/sites/default/files/media_asset/UNAIDS_FactSheet_en.pdf.

2. Bezabhe, W., Peterson, G., Bereznicki, L., Chalmers, L., \& Gee, P. (2013). Adherence to antiretroviral drug therapy in adult patients who are HIVpositive in Northwest Ethiopia: A study protocol. BMJ Open, 3(10), e003559.

3. lacob, S. A., lacob, D. G., \& Jugulete, G. (2017). Improving the adherence to antiretroviral therapy, a difficult but essential task for a successful HIV treatment-Clinical points of view and practical considerations. Frontiers in Pharmacology, 8, 831.

4. Viswanathan, S., Detels, R., Mehta, S. H., Macatangay, B. J. C., Kirk, G. D., \& Jacobson, L. P. (2015). Level of adherence and HIV RNA suppression in the current era of highly active antiretroviral therapy (HAART). AIDS and Behavior, 19(4), 601-611.

5. Shubber, Z., Mills, E. J., Nachega, J. B., Vreeman, R., Freitas, M., Bock, P., et al. (2016). Patient-reported barriers to adherence to antiretroviral therapy: A systematic review and meta-analysis. PLoS Med, 13(11), e1002183.

6. U.S. Department of Health and Human Services, Panel on Antiretroviral Guidelines for Adults and Adolescents. (2017). Guidelines for the use of antiretroviral agents in HIV-1-infected adults and adolescents. Retrieved from https://aidsinfo.nih.gov/contentfiles/lvguidelines/adultandadolescentgl. pdf

7. Genberg, B. L., Lee, Y., Rogers, W. H., \& Wilson, I. B. (2015). Four types of barriers to adherence of antiretroviral therapy are associated with decreased adherence over time. AIDS and Behavior, 19(1), 85-92.

8. Wiering, B., de Boer, B. D., \& Delnoij, D. (2017). Patient involvement in the development of patient-reported outcome measures: The developers' perspective. BMC Health Services Research, 17, 1.

9. Crane, H. M., Crane, P. K., Tufano, J. T., Ralston, J. D., Wilson, I. B., Brown, T. D., Davis, T. E., et al. (2017). HIV provider documentation and actions following patient reports of at-risk behaviors and conditions when identified by a web-based point-of-care assessment. AIDS and Behavior, 21(11), 3111-3121.

10. Kozak, M. S., Mugavero, M. J., Ye, J., Aban, I., Lawrence, S. T., Nevin, C. R., Raper, J. L., McCullumsmith, C., Schumacher, J. E., Crane, H. M., Kitahata, M. M., Saag, M. S., et al. (2012). Patient reported outcomes in routine care: Advancing data capture for HIV cohort research. Clinical Infectious Diseases, 54(1), 141-147.

11. Engler, K., Lessard, D., \& Lebouché, B. (2017). A review of HIV-specific patient-reported outcome measures. The Patient, 10(2), 187-202.

12. Terwee, C., Prinsen, C. A. C., Chiarotto, A., Westerman, M. J., Patrick, D. L., Alonso, J., et al. (2018). Cosmin methodology for evaluating the content validity of patient-reported outcome measures: A Delphi study. Quality of Life Research, 27(5), 1159-1170.

13. Engler, K., Lènàrt, A., Lessard, D., Toupin, I., \& Lebouché, B. (2018). Barriers to antiretroviral therapy adherence in developed countries: A qualitative synthesis to develop a conceptual framework for a new patient-reported outcome measure. AIDS Care, 30(sup1), 17-28.

14. McHugh, M. L. (2012). Interrater reliability: The kappa statistic. Biochemia Medica, 22(3), 276-282

15. World Economic Situation and Prospects. (2012). Country classification. Retrieved from http://www.un.org/en/development/desa/policy/wesp/ wesp_current/2012country_class.pdf

16. Wiering, B. M., de Boer, B. D., \& Delnoij, D. (2017). Patient involvement in the development of patient-reported outcome measures: A scoping review. Health Expectations, 20(1), 11-23. 
17. O'Brien, K. K., Bayoumi, A. M., Strike, C., Young, N. L., King, K., \& Davis, A. M. (2010). How do existing HIV-specific instruments measure up? Evaluating the ability of instruments to describe disability experienced by adults living with HIV. Health and Quality of Life Outcomes, 8, 88.

18. Elo, S., \& Kyngäs, H. (2008). The qualitative content analysis process. Journal of Advanced Nursing, 62(1), 107-115.

19. Bangsberg, D. R., Bronstone, A., \& Hofman, R. (2002). A computer/ based assessment detects regimen misunderstandings and nonadherence for patients on HIV antiretroviral therapy. AIDS Care, 1, 3-15.

20. Heckman, B. D., Catz, S. L., Heckman, T. G., Miller, J. G., \& Kalichman, S. C. (2004). Adherence to antiretroviral therapy in rural persons living with HIV disease in the United States. AIDS Care, 16(2), 219-230.

21. Chesney, M. A., Chambers, D. B., Gifford, A. L., Neidig, J., Zwicki, B., Wu, A. W., \& Patient Care Committee \& Adherence Working Group of the Outcomes Committee of the Adult AIDS Clinical Trials Group. (2000). Self-reported adherence to antiretroviral medications among participants in HIV clinical trials: The AACTG adherence instruments. AIDS Care, 12, 255-266.

22. Amico, R. K., Konkle-Parker, D. J., Cornman, D. H., Barta, W. D., Ferrer, R., Norton, W. E., et al. (2007). Reasons for ART non-adherence in the Deep South: Adherence needs of a sample of HIVpositive patients in Mississippi. AIDS Care, 19(10), 1210-1218.

23. Barfod, T., Sørensen, H., Nielsen, H., Rodkjær, L., \& Obel, N. (2006). Simply forgot' is the most frequently stated reason for missed doses of HAART irrespective of degree of adherence. HIV Medicine, 7(5), 285-290.

24. Boretzki, J., Wolf, E., Wiese, C., Noe, S., Balogh, A., Meurer, A., et al. (2017). Highly specific reasons for nonadherence to antiretroviral therapy: Results from the German adherence study. Patient Preference and Adherence, 11, 1897-1906.

25. Dima, A., Schweitzer, A., Diaconita, R., Remor, E., \& Wanless, R. (2013). Adherence to ARV medication in Romanian young adults: Self-reported behaviour and psychological barriers. Psychology, Health \& Medicine, 18(3), 343-354.

26. Durante, A., Bova, C., Fennie, K., Danvers, K., Holness, D., Burgess, J., \& Williams, A. (2003). Home-based study of anti-hiv drug regimen adherence among HIV-infected women: Feasibility and preliminary results. AIDS Care, 15(1), 103-115.

27. Gifford, A., Bormann, J., Shively, M., Wright, B., Richman, D., \& Bozzette, S. (2000). Predictors of self-reported adherence and plasma HIV concentrations in patients on multidrug antiretroviral regimens. Journal of Acquired Immune Deficiency Syndromes, 23(5), 386-395.

28. Godin, G., Gagné, C., \& Naccache, H. (2003). Validation of a self-reported questionnaire assessing adherence to antiretroviral medication. AIDS Patient Care and STDs, 17(7), 325-332.

29. Grierson, J., Misson, S., \& Pitts, M. (2004). Correlates of antiretroviral treatment breaks. HIV Medicine, 5(1), 34-39.

30. Grierson, J., Pitts, M., \& Koelmeyer, R. (2013). In La Trobe University (Ed.), HIV Futures Seven: the health and wellbeing of HIV positive people in Australia. Monograph series number 88, The Australian Research Centre in Sex. Melbourne, Australia: Health and Society.

31. Harzke, A., Williams, M., Nilsson-Schönnesson, L., Ross, M., Timpson, S., \& Keel, K. (2004). Psychosocial factors associated with adherence to antiretroviral medications in a sample of HIVpositive African American drug users. AIDS Care, 16(4), 458-470.

32. Kalichman, S., Ramachandran, B., \& Catz, S. (1999). Adherence to combination antiretroviral therapies in HIV patients of low health literacy. Journal of General Internal Medicine, 14(5), 267-273.

33. Kalichman, S., Kalichman, M., \& Cherry, C. (2017). Forget about forgetting structural barriers and severe non-adherence to antiretroviral therapy. AIDS Care, 29(4), 418-422.

34. Kerr, T., Palepu, A., Barness, G., Walsh, J., Hogg, R., Montaner, J., et al. (2004). Psychosocial determinants of adherence to highly active antiretroviral therapy among injection drug users in Vancouver. Antiviral Therapy, 9(3), 407-414.

35. Kerr, T., Marshall, A., Walsh, J., Palepu, A., Tyndall, M., Montaner, J., et al. (2005). Determinants of HAART discontinuation among injection drug users. AIDS Care, 17(5), 539-549.

36. Kleeberger, C., Phair, J., Strathdee, S., Detels, R., Kingsley, L., \& Jacobson, L. (2001). Determinants of heterogeneous adherence to HIV-antiretroviral therapies in the Multicenter AIDS Cohort Study. Journal of Acquired Immune Deficiency Syndromes, 26(1), 82-92.
37. Kyser, M., Buchacz, K., Bush, T., Conley, L., Hammer, J., Henry, K., et al. (2011). Factors associated with non-adherence to antiretroviral therapy in the SUN Study. AIDS Care, 23(5), 601-611.

38. MacDonell, K., Naar-King, S., Huszti, H., \& Belzer, M. (2013). Barriers to medication adherence in behaviorally and perinatally infected youth living with HIV. AIDS and Behavior, 17(1), 86-93.

39. Mannheimer, S., Friedland, G., Matts, J., Child, C., Chesney, M., \& Terry Beirn Community Programs for Clinical Research on AIDS. (2002). The consistency of adherence to antiretroviral therapy predicts biologic outcomes for human immunodeficiency virus-infected persons in clinical trials. Clinical Infectious Diseases, 34(8), 1115-1121.

40. Murphy, D., Roberts, K., Martin, D., Marelich, W., \& Hoffman, D. (2000). Barriers to antiretroviral adherence among HIV-infected adults. AIDS Patient Care and STDs, 14(1), 47-58

41. Murphy, D., Sarr, M., Durako, S., Moscicki, A., Wilson, C., Muenz, L., \& Adolescent Medicine HIV/AIDS Research Network. (2003). Barriers to HAART adherence among human immunodeficiency virus-infected adolescents. Archives of Pediatrics \& Adolescent Medicine, 157(3), 249-255.

42. Schuman, P., Ohmit, S., Cohen, M., Sacks, H., Richardson, J., Young, M., et al. (2001). Prescription of and adherence to antiretroviral therapy among women with aids. AIDS and Behavior, 5(4), 371-378.

43. Schönnesson, L., Ross, M., \& Williams, M. (2004). The HIV medication selfreported nonadherence reasons (SNAR) index and its underlying psychological dimensions. AIDS and Behavior, 8(3), 293-301.

44. Stirratt, M., The SMART Couples Study Team, Remien, R., Smith, A., Copeland, O. Dolezal, C. \& Krieger, D. (2006). The role of HIV serostatus disclosure in antiretroviral medication adherence. AIDS and Behavior, 10(5), 483-493.

45. Walsh, J., Horne, R., Dalton, M., Burgess, A., \& Gazzard, B. (2001). Reasons for non-adherence to antiretroviral therapy: Patients' perspectives provide evidence of multiple causes. AIDS Care, 13(6), 709-720.

46. Zorilla, C. D., Santiago, L. E., Knubson, D., Liberatore, K., Estronza, G., Colon, O., \& Acevedo, M. (2003). Greater adherence to highly active antiretroviral therapy (HAART) between pregnant versus non-pregnant women living with HIV. Cellular \& Molecular Biology, 49(8), 1187-1192.

47. McAllister, J., Beardsworth, G., Lavie, E., MacRae, K., \& Carr, A. (2013). Financial stress is associated with reduced treatment adherence in HIV-infected adults in a resource-rich setting. HIV Medicine, 14(2), 120-124.

48. World Health Organization. (2003). Adherence to long-term therapies: Evidence for action. Geneva: Author.

49. Engler, K., Ahmed, S., Lessard, D. Vicente, S., Lebouché, B. (under review). Assessing the content validity, actionability, and cross-cultural equivalence of a new patient-reported outcome measure of barriers to antiretroviral therapy adherence for electronic administration in routine HIV care: protocol for an online Delphi study. JMIR Research Protocols, JMIR Preprints. Retrieved from: https://preprints.jmir.org/preprint/12836

\section{Submit your manuscript to a SpringerOpen ${ }^{\circ}$ journal and benefit from:}

- Convenient online submission

- Rigorous peer review

- Open access: articles freely available online

- High visibility within the field

- Retaining the copyright to your article

Submit your next manuscript at $>$ springeropen.com 